\title{
An evaluation of Panicum maximum cv. Gatton: 2. The influence of stage of maturity on diet selection, intake and rumen fermentation in sheep
}

\author{
E.A. Relling, W.A. van Niekerk ${ }^{\#}$, R.J. Coertze and N.F.G. Rethman ${ }^{1}$ \\ Department of Animal and Wildlife Sciences, University of Pretoria, Pretoria 0002, South Africa \\ ${ }^{1}$ Department of Plant Production \& Soil Science, University of Pretoria, Pretoria 0002, South Africa
}

\begin{abstract}
The aim of the study was to evaluate the nutritional value of Panicum maximum cv. Gatton for sheep production in three different seasons and at three different stages of maturity. More mature pasture, compared to younger pasture, resulted in lower quality being selected. This was reflected in lower $\mathrm{N}$ values, lower digestibility and higher NDF, ADF and ADL values in selected material. Digestible organic matter intake (DOMI) also decreased with maturity. Grazing of more mature pasture resulted in lower rumen ammonia nitrogen $\left(\mathrm{NH}_{3}-\mathrm{N}\right)$ levels and higher acetic:propionic acid ratios. This trend was noted in all seasons. The nutritional value of the pasture in summer was high enough to meet at least the maintenance requirements of sheep in all stages of maturity evaluated. The nutritional value of the young and medium mature autumn pasture was also high enough to meet at least the maintenance requirements, but at the mature stage intake was too low. Intake in winter at all stages of maturity, was too low to meet the maintenance requirements of sheep.
\end{abstract}

Keywords: Panicum maximum, nutrition, rumen, sheep.

\#Author to whom correspondence should be addressed; e-mail: wvniekerk@ postino.up.ac.za

\section{Introduction}

The stage of maturity of pasture influences forage quality and hence voluntary intake and selection by sheep. The decrease in quality and intake with advancing stage of pasture maturity is well documented (Minson, 1972; Aii \& Stobbs, 1980; Garcell \& Poppe, 1989; Wan Hassan et al., 1990; Cilliers \& Van der Merwe, 1993; Kabunga \& Darko, 1993). Although there are numerous reports on the effect of stage of maturity on the nutritive value of tropical pastures, there is a paucity of data for $P$. maximum cv. Gatton grown under dryland conditions. The aim of this study was to evaluate how the stage of maturity of Panicum maximum cv. Gatton grown under dryland conditions influences quality of material selected, intake and certain rumen parameters when grazed by sheep during various seasons of the year.

\section{Materials and methods}

The study was conducted at the Hatfield Experimental Farm of the University of Pretoria. The site is situated at $28.11^{\circ} \mathrm{E} ; 25.44^{\circ} \mathrm{S}$ at an altitude of $1372 \mathrm{~m}$, and has an average annual rainfall of $674 \mathrm{~mm}$ with a dry autumn and winter. The $P$. maximum pasture was established under dryland conditions, and was fertilized with $700 \mathrm{~kg}$ limestone ammonium nitrate $(28 \% \mathrm{~N})$ per ha in two equal dressings in spring and mid-summer, plus a single spring application of $300 \mathrm{~kg} \mathrm{KCl} / \mathrm{ha}$.

Three camps of 0.24 ha each were used. These were subdivided into three smaller camps that were manipulated to produce young, early reproductive or mature stage pastures by mowing the three subsections in each camp at different intervals. The periods of pasture re-growth were 84,42 and $21 \mathrm{~d}$ for the mature, medium and young growth stages, respectively. The pasture was planted on 7 November 1989 and mowing for the summer, autumn and winter season treatments was commenced on 18 February, 12 April and 6 June respectively of the following year (1990).

Twelve Döhne-Merino wethers equipped with rumen, abomasal and terminal ileal fistulas were randomly allocated to the three treatments. An additional 15 wethers were allocated to the three treatments, and fitted with faecal collection bags to determine voluntary intake. Three oesophageal fistulated sheep, randomly allocated to each treatment, were used to estimate the quality of plant material selected at each stage of maturity. All the animals were treated against internal parasites, inoculated against pulpy kidney disease and injected with vitamin A two weeks prior to the start of the experimental period. The treatment against internal parasites were repeated every six weeks. The animals had ad lib. access to a 50:50 
dicalciumphosphate/salt lick, and fresh water was available at all times. Rumen samples were collected at the times shown in Table 1.

Table 1 Schedule used for sampling of rumen fluid

\begin{tabular}{cccc}
\hline Day 1 & Day 2 & Day 3 & Day 4 \\
\hline $9 \mathrm{~h} 00$ & $12 \mathrm{~h} 00$ & $15 \mathrm{~h} 00$ & $18 \mathrm{~h} 00$ \\
$21 \mathrm{~h} 00$ & $24 \mathrm{~h} 00$ & $3 \mathrm{~h} 00$ & $6 \mathrm{~h} 00$ \\
\hline
\end{tabular}

Rumen fluid $(100 \mathrm{ml})$ was extracted from different sites in the rumen with a syringe. The liquid was filtered through a layer of cheesecloth, and the $\mathrm{pH}$ was measured. Fifty $\mathrm{ml}$ of the sample was preserved with $2 \mathrm{ml} 0.5 \mathrm{M} \mathrm{H}_{2} \mathrm{SO}_{4}$ solution. Samples were pooled for each period and frozen until analysis for $\mathrm{NH}_{3}-\mathrm{N}$ concentrations by an automated procedure (Technicon Auto Analyser II: Industrial method no. 334 - 74A). Fifty $\mathrm{ml}$ of the rumen fluid drawn was preserved with $1 \mathrm{ml} 0.10 \% \mathrm{NaOH}$ solution and added to a frozen composite sample until volatile fatty acid analysis by gas chromatography. Samples were collected from three oesophageal-fistulated sheep for each pasture at the beginning and end of the grazing periods used for rumen sampling. They were denied access to feed for three hours before the commencement of sampling, and were allowed to graze for 45 minutes during which samples were collected. Saliva was removed through a double layer of cheesecloth as described by Engels et al. (1981). The samples were frozen and analysed for in vitro digestible organic matter (IvDOM; Tilley \& Terry, 1963 as modified by Engels \& Van der Merwe, 1967), N (macro Kjedahl method of AOAC, 1995), NDF according to Robertson \& Van Soest (1981) and ADF and ADL according to Goering \& Van Soest (1970). For each treatment five sheep were fitted with faecal collection bags one week prior to the start of the rumen sampling period. The duration of the fecal collection period was 10 days. Digestible organic matter intake (DOMI) was determined from faecal output (Langlands, 1975) by converting in vitro digestibility to in vivo digestibility according to Engels et al. (1981).

An analysis of variance for balanced data with the ANOVA model (Statistical Analysis Systems, 1994) and the Tukey t-test (Samuels, 1989) was used to determine the effects of stage of maturity and season.

\section{Results and Discussion}

Pasture quality parameters decreased from the young to mature stages in summer, autumn and winter (Table 2). These differences may have arisen from either of two sources: selection behaviour of sheep may differ between levels of maturity (O`Reagain \& Owen-Smith, 1996) or plant composition may differ between levels of maturity (Aii \& Stobbs, 1980). O'Reagain et al. (1996) reported that the presence of an increased proportion of plant stems, typical of older plants, may restrict access to leafy parts and force animals to consume lower quality herbage. O`Reagain \& Owen-Smith (1996) also noted that sward greenness is positively correlated with the selection of a high quality diet. The quality of available bites is depressed when green leaf-material is scarce and largely dispersed among senescent material. These factors could explain the results of this experiment, especially in the case of the older autumn pasture for which the NDF and ADL fractions increased with level of maturity. The nitrogen content of pasture also decreased from the young to mature stages in summer, autumn and winter, although differences were not statistically significant for all means (Table 2). Various authors have reported the same trend for P. maximum (Gomide et al., 1969; Aii \& Stobbs, 1980; Dzowela et al., 1990; Wan Hassan et al., 1990; Singh et al., 1995). The ADF, ADL and NDF fractions differed between stages of maturity for all seasons; the youngest and the oldest stages differed for all seasons except for ADF in autumn. The ADF concentration for autumn was lowest for the medium stage of maturity, followed by the young and then the mature stage. The reason for this is not clear, since several authors have shown that NDF, ADF and ADL concentrations increase with stage of maturity (Garcell \& Poppe, 1989; Buxton, 1991; Jung \& Vogel, 1992; Kephart \& Buxton, 1993; Hatfield et al., 1994). 
Table 2 Mean ( \pm s.d.) chemical composition of oesophageal samples collected from sheep grazing $P$. maximum cv. Gatton pastures at different levels of maturity during summer, autumn or winter

\begin{tabular}{crrr}
\hline & Young & Medium & Mature \\
\hline Summer & & & \\
\hline $\mathrm{N} \%$ & $2.9^{\mathrm{a}}(0.1)$ & $2.8^{\mathrm{a}}(0.1)$ & $2.0^{\mathrm{b}}(0.2)$ \\
NDF \% & $46.2^{\mathrm{b}}(1.3)$ & $52.1^{\mathrm{a}}(0.8)$ & $54.1^{\mathrm{a}}(1.1)$ \\
ADF \% & $23.1^{\mathrm{c}}(1.3)$ & $24.7^{\mathrm{b}}(0.3)$ & $28.9^{\mathrm{a}}(0.1)$ \\
ADL \% & $2.4^{\mathrm{c}}(0.3)$ & $3.4^{\mathrm{b}}(0.3)$ & $4.2^{\mathrm{a}}(0.3)$ \\
IvDOM \% & $76.9^{\mathrm{a}}(0.8)$ & $69.6^{\mathrm{b}}(1.1)$ & $64.3^{\mathrm{c}}(1.1)$ \\
Autumn & & & \\
$\mathrm{N} \%$ & $2.0^{\mathrm{a}}(0.1)$ & $1.9^{\mathrm{b}}(0.1)$ & $1.8^{\mathrm{b}}(0.1)$ \\
NDF \% & $51.9^{\mathrm{c}}(0.4)$ & $55.6^{\mathrm{b}}(0.5)$ & $59.5^{\mathrm{a}}(0.5)$ \\
ADF \% & $28.8^{\mathrm{b}}(0.2)$ & $25.7^{\mathrm{c}}(0.3)$ & $30.8^{\mathrm{a}}(0.5)$ \\
ADL \% & $3.3^{\mathrm{b}}(0.2)$ & $4.0^{\mathrm{a}}(0.4)$ & $4.1^{\mathrm{a}}(0.1)$ \\
IvDOM \% & $68.9^{\mathrm{a}}(0.9)$ & $65.4^{\mathrm{b}}(1.1)$ & $61.6^{\mathrm{c}}(1.0)$ \\
Winter & & & \\
\hline $\mathrm{N} \%$ & $1.8^{\mathrm{a}}(0.1)$ & $1.9^{\mathrm{a}}(0.1)$ & $1.5^{\mathrm{b}}(0.1)$ \\
NDF \% & $52.5^{\mathrm{c}}(0.5)$ & $59.2^{\mathrm{b}}(0.5)$ & $63.8^{\mathrm{a}}(0.6)$ \\
ADF \% & $27.1^{\mathrm{c}}(0.9)$ & $29.9^{\mathrm{b}}(1.4)$ & $35.7^{\mathrm{a}}(1.1)$ \\
ADL \% & $4.0^{\mathrm{b}}(0.1)$ & $4.3^{\mathrm{b}}(0.2)$ & $5.6^{\mathrm{a}}(0.1)$ \\
IvDOM \% & $62.5^{\mathrm{a}}(1.1)$ & $60.4^{\mathrm{a}}(1.9)$ & $55.4^{\mathrm{b}}(1.2)$ \\
\hline
\end{tabular}

$\overline{a, b, c}$ Row means with common superscripts do not differ $(\mathrm{P}>0.05)$

Digestibility decreased with level of maturity in all seasons except winter (Table 2) in agreement with reports showing that a decrease in N content and an increase in NDF, ADF and ADL content is associated with a decrease in digestibility (Ford et al., 1979; Cilliers \& Van der Merwe, 1993).

Table 3 Mean ( \pm s.d.) digestible organic matter intake $\left(\mathrm{g} / \mathrm{kg} \mathrm{w}^{0.75} / \mathrm{d}\right)$ of sheep grazing P. maximum cv. Gatton at different levels of maturity in summer, autumn or winter

\begin{tabular}{lccc}
\hline & Young & Medium & Mature \\
\hline Summer & $60^{\mathrm{a}}(5)$ & $57^{\mathrm{a}}(5)$ & $48^{\mathrm{b}}(1)$ \\
Autumn & $49^{\mathrm{a}}(5)$ & $44^{\mathrm{a}}(2)$ & $27^{\mathrm{b}}(4)$ \\
Winter & $27^{\mathrm{a}}(3)$ & $26^{\mathrm{a}}(4)$ & $23^{\mathrm{a}}(2)$ \\
\hline
\end{tabular}

a,b,c Row means with common superscripts do not differ $(\mathrm{P}>0.05)$

Digestible organic matter intake (DOMI) decreased from young to mature pastures in summer and autumn (Table 3). Minson (1972) also reported a drop in voluntary DOMI with increasing regrowth period. The decrease in quality of the material selected (Table 2) corresponded well with the decrease in intake. Van Soest (1965) and Cilliers \& Van der Merwe (1993) reported similar results for animals grazing pastures of decreasing quality. Laredo \& Minson (1973) and Minson (1982) reported a negative relationship between intake and the NDF, ADF and ADL content of grasses, however Minson (1971), Laredo \& Minson (1973) and Minson (1982) noted a positive relationship between digestibility and intake. No differences between stage of maturity were observed in winter for DOMI. A decrease was, however, observed in terms of the quality of material selected, which corresponded with the pattern observed for the other seasons. Intake in winter was, however, lower than in the other seasons (Table 3). Barthram (1980) found that grazing sheep seldom penetrated into horizons containing dead material, even if herbage intake was severely limited as a consequence. It is possible that this effect could have been a factor in this particular season.

Engels (1972) found that the maintenance intake requirement for sheep was $33.5 \mathrm{~g} \mathrm{DOM} / \mathrm{kg} \mathrm{W}^{0.75} / \mathrm{d}$ which indicates that the DOMI in summer would, at least, have been able to satisfy maintenance requirements. The mean values for young and medium stage autumn pasture were also above this value, but 
the intake of mature autumn grazing was too low to satisfy maintenance requirements. In winter DOMI at all stages was below this level.

Table 4 Mean ( \pm s.d.) concentrations of metabolites and molar proportions of individual volatile fatty acids (VFA) in the rumen of sheep grazing P. maximum cv. Gatton pasture at various stages of maturity in summer, autumn or winter

\begin{tabular}{llll}
\hline & \multicolumn{3}{c}{ Stage of plant maturity } \\
\cline { 2 - 4 } & Young & Medium & Mature \\
\hline Summer & & & \\
$\mathrm{NH}_{3}-\mathrm{N}(\mathrm{mg} / 100 \mathrm{ml})$ & $32.2^{\mathrm{a}}(4.9)$ & $23.5^{\mathrm{b}}(1.4)$ & $17.3^{\mathrm{b}}(1.9)$ \\
$\mathrm{VFA}(\mathrm{mmol} / 100 \mathrm{ml})$ & $22.8^{\mathrm{a}}(2.8)$ & $19.8^{\mathrm{ab}}(1.2)$ & $18.5^{\mathrm{b}}(2.0)$ \\
Acetic acid (\%) & $70(1.5)$ & $70(1.4)$ & $71(1.2)$ \\
Propionic acid (\%) & $21^{\mathrm{a}}(0.4)$ & $19^{\mathrm{ab}}(0.5)$ & $17^{\mathrm{b}}(0.6)$ \\
Butyric acid (\%) & $9(0.3)$ & $11(0.8)$ & $11(0.6)$ \\
Acetic/propionic & $3.4^{\mathrm{b}}(0.3)$ & $3.7^{\mathrm{a}^{\mathrm{b}}}(0.2)$ & $4.1^{\mathrm{a}}(0.2)$ \\
Autumn & & & \\
$\mathrm{NH}_{3}-\mathrm{N}(\mathrm{mg} / 100 \mathrm{ml})$ & $18.6^{\mathrm{a}}(1.2)$ & $16.3^{\mathrm{a}}(1.4)$ & $8.9^{\mathrm{b}}(1.1)$ \\
$\mathrm{VFA}(\mathrm{mmol} / 100 \mathrm{ml})$ & $18.7^{\mathrm{a}}(1.2)$ & $18.4^{\mathrm{a}}(0.8)$ & $13.7^{\mathrm{b}}(1.6)$ \\
Acetic acid $(\%)$ & $72^{\mathrm{b}}(0.5)$ & $73^{\mathrm{ab}}(0.5)$ & $74^{\mathrm{a}}(0.6)$ \\
Propionic acid $(\%)$ & $21^{\mathrm{a}}(0.8)$ & $18^{\mathrm{b}}(0.7)$ & $16^{\mathrm{c}}(0.5)$ \\
Butyric acid (\%) & $8^{\mathrm{b}}(0.2)$ & $9^{\mathrm{a}}(0.2)$ & $10^{\mathrm{a}}(0.7)$ \\
Acetic/propionic & $3.5^{\mathrm{c}}(0.3)$ & $4.0^{\mathrm{b}}(0.2)$ & $4.6^{\mathrm{a}}(0.3)$ \\
Winter & & & \\
$\mathrm{NH} \mathrm{H}_{3}-\mathrm{N}(\mathrm{mg} / 100 \mathrm{ml})$ & $10.0^{\mathrm{a}}(0.7)$ & $8.4^{\mathrm{a}}(1.4)$ & $5.3^{\mathrm{b}}(1.1)$ \\
VFA (mmol/100ml) & $17.6^{\mathrm{a}}(1.8)$ & $16.3^{\mathrm{ab}}(0.5)$ & $15.0^{\mathrm{b}}(0.9)$ \\
Acetic acid $(\%)$ & $69^{\mathrm{b}}(0.6)$ & $74^{\mathrm{a}}(0.7)$ & $74^{\mathrm{a}}(0.5)$ \\
Propionic acid $(\%)$ & $17^{\mathrm{a}}(0.5)$ & $16^{\mathrm{a}}(0.6)$ & $16^{\mathrm{a}}(0.5)$ \\
Butyric acid (\%) & $12^{\mathrm{a}}(0.2)$ & $9^{\mathrm{b}}(0.3)$ & $9^{\mathrm{b}}(0.4)$ \\
Acetic/propionic & $4.0^{\mathrm{b}}(0.2)$ & $4.5^{\mathrm{a}}(0.2)$ & $4.7^{\mathrm{a}}(0.3)$ \\
\hline
\end{tabular}

${ }^{a, b, c}$ Row means with common superscripts do not differ $(\mathrm{P}>0.05)$

Rumen $\mathrm{NH}_{3}-\mathrm{N}$ levels decreased as pasture matured during all seasons (Table 4). Hogan et al. (1969) also observed a decrease in rumen $\mathrm{NH}_{3}-\mathrm{N}$ levels with advancing forage maturity. Rumen $\mathrm{NH}_{3}-\mathrm{N}$ concentrations were the highest in summer, followed by autumn and winter which corresponds with the results of Meissner et al. (1993). $\mathrm{N}$ intake decreased with level of maturity, as discussed previously (Table 3). A positive correlation between $\mathrm{N}$ intake and rumen $\mathrm{NH}_{3}-\mathrm{N}$ concentrations was also observed by Meissner et al. (1993). Although rumen $\mathrm{NH}_{3}$ concentrations are not only a function of $\mathrm{N}$ content, but of $\mathrm{N}$ solubility, energy content of the diet and level of intake (Van Soest, 1982), N content accounted for up to $81 \%$ of the variation in rumen $\mathrm{NH}_{3}$ concentration in the study of Meissner et al. (1993). The high $\mathrm{N}$ content of the young and medium pastures in this study was accompanied by high rumen $\mathrm{NH}_{3}-\mathrm{N}$ concentrations. Satter \& Slyter (1974) reported a positive response in microbial yield at a pasture N content of below 2.5\%, but not above. Increased $\mathrm{N}$ losses, in the form of $\mathrm{NH}_{3} \mathrm{~N}$, occurred above $2.5 \% \mathrm{~N}$ in the pasture. This possibly explains the relatively high values for $\mathrm{NH}_{3}-\mathrm{N}$ concentrations observed for young and medium

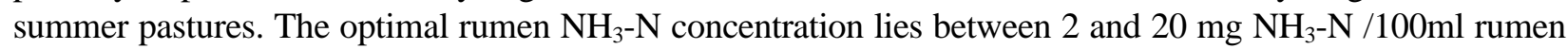
fluid (see Meissner et al., 1993). For maximum microbial yield in the rumen, $5 \mathrm{mg} \mathrm{NH}-\mathrm{N} / 100 \mathrm{ml}$ rumen fluid is sufficient, while $20-24 \mathrm{mg} \mathrm{NH}-\mathrm{N} / 100 \mathrm{ml}$ is required for maximum fermentation rate ( $\theta$ rskov, 1982). With grazing animals, maximum fermentation rate is more important than maximum microbial yield, as the former leads to higher intake and nutrient supply (Boniface et al., 1986). The mean rumen $\mathrm{NH}_{3}-\mathrm{N}$ concentration for the medium and mature stages during summer was within the range for maximum fermentation rate as defined by $\theta$ rskov (1982). Mean rumen $\mathrm{NH}_{3}-\mathrm{N}$ concentrations for autumn and winter were between the limits for optimal rumen function as defined by Meissner et al. (1993). Rumen $\mathrm{NH}_{3}-\mathrm{N}$ concentrations for the mature stage in winter approached the maximum microbial yield value as defined by Orskov (1982). This may explain the lower intakes observed during winter at the more mature stages (Table 
3). However, as discussed previously, there are a number of factors that influence intake at different stages of herbage maturity.

Total volatile fatty acid production decreased as herbage reached maturity (Table 4). The results of Hogan et al. (1969) and Playne \& Kennedy (1976) are in concordance with these findings. Proportions of propionic acid decreased $(\mathrm{P}<0.05)$ as herbage matured during summer and autumn. A high proportion of propionic acid is also associated with high-quality plant material (Meissner et al., 1993). Walker et al. (1975) indicated that hay diets resulted in a lower total VFA production rate compared to green succulent feed, possibly explaining the lower value observed at the mature stage in winter compared to the other seasons.

An increase in the ratio of acetic to propionic acid occurred during all three seasons as herbage matured (Table 4). The ratio of acetic to propionic acid is also linked to forage quality. A high ratio of acetic to propionic acid could result in less efficient utilization of $\mathrm{NH}_{3}-\mathrm{N}$ (Playne \& Kennedy, 1976). Acetic and butyric acid can only be utilised for tissue growth and production if sufficient propionic acid is available (Annison \& Armstrong, 1970). MacRae \& Lobley (1982) stated that acetic acid was only utilized inefficiently at low propionic acid levels when the $\mathrm{N}$ or glucose supply from the diet was low. It is conceivable that the summer decrease in propionic acid could potentially have decreased acetic acid utilization, but this is unlikely, given the relative abundance of $\mathrm{N}$ in forage during this period. The ratio of acetic to propionic acid increased $(\mathrm{P}<0.05)$ with level of maturity for all seasons, indicating that a more mature pasture is associated with lower quality material. During winter the high ratio of acetic to propionic acid for mature-stage pastures, together with a low pasture $\mathrm{N}$ content, could have resulted in inefficient utilization of acetic acid, which could have influenced the performance of animals in this treatment. MacRae et al. (1985) reported that animals fed roughage diets of low $\mathrm{N}$ content may utilize acetic acid less efficiently.

\section{Conclusions}

Increased pasture maturity had a negative effect on the nutritional value of $P$. maximum $\mathrm{cv}$. Gatton pasture, indicating that this forage would be best utilized at younger stages of development. Digestible organic matter intake was too low to satisfy maintenance requirements of grazing sheep in mature autumn pasture and at all three stages of pasture maturity in winter pasture. The decrease in intake, together with lower digestibility at mature stages in winter and autumn indicates that supplementary feeding would be necessary at these times.

\section{References}

Annison, E.F. \& Armstrong, D.G., 1970. Physiology of digestion and metabolism in the ruminant. Ed. Phillipson A., Oriel Press, Newcastle-upon-Tyne, England. pp. 422.

AOAC, 1995. Official methods of analysis of the Association of Official Analytical Chemists (16 ${ }^{\text {th }}$ ed.). Arlington, Virginia, U.S.A.

Aii, T. \& Stobbs, T.H., 1980. Solubility of the protein of tropical pasture species and the rate of digestion in the rumen. Anim. Feed Sci. Tech. 5, 183.

Barthram, G.T., 1980. Sward structure and the depth of the grazed horizon. Proceedings of the British Grassland Society Winter meeting 1980. Grass Forage Sci. 36, 130.

Boniface, A.N., Murray, R.M. \& Hogan, J.P., 1986. Optimum level of ammonia in rumen liquor of cattle fed tropical pasture hay. Proc. Aust. Soc. Anim. Prod. 16, 151.

Buxton, D.R., 1991. Digestibility by rumen micro-organisms of neutral sugars in perennial forage stems and leaves. Anim. Feed Sci. Tech. 32, 119.

Chapman, H.W. \& Grovum, W.L., 1984. Oesophageal fistulation of sheep for sham feeding studies. Can. J. Anim. Sci. (Suppl.) pp.106.

Cilliers, J.W. \& Van der Merwe, H.J., 1993. Relationships between chemical components of veld herbage and in vitro digestibility and estimated intakes of dry matter and ingestible dry matter by sheep and cattle. Anim. Feed Sci. Tech. 43, 151. 
Dzowela, B.H., Kumwenda, M.S.L., Msiska, H.D.C., Hodges, E.M. \& Gray, R.C., 1990. Seasonal trends in forage dry matter production of some improved pastures and animal performance in relation to chemical composition in Malawi. Anim. Feed Sci. Tech. 28, 255.

Engels, E.A.N. \& Van der Merwe, F.J., 1967. Application of an in vitro technique to South African forages with special reference to the effect of certain factors on the result. S. Afr. J. Anim. Sci. 10, 983.

Engels, E.A.N., 1972. A study of the nutritive value of natural and sown pastures in the central Orange Free State with special reference to the energy requirements of sheep. Ph.D. Thesis, University of Stellenbosch.

Engels, E.A.N., De Waal, H.O., Biel, L.C. \& Malan, A., 1981. Practical implications of the effect of drying and treatment on nitrogen content and in vitro digestibility of samples collected by oesophageal fistulated animals. S. Afr. J. Anim. Sci. 11, 247.

Ford, C.W., Morrison, I.M. \& Wilson, J.R., 1979. Temperature effects on lignin, hemicellulose and cellulose in tropical and temperate grasses. Aust. J. Agric. Res. 30, 621.

Garcell, A. \& Poppe, S., 1989. Studies on feed value of Bermuda grass cross No. 1 (Cynodon dactylon) in Cuba. Arch. Anim. Nutr. 39, 193.

Goering, H.K. \& Van Soest, P.J., 1970. Forage fibre analysis (apparatus, reagents, procedures and some applications). Agriculture Handbook no. 379, A.R.S., U.S. Dept. of Agric.

Gomide, J.A., Noller, C.H., Mott, G.O., Conrad, J.H. \& Hill, D.L., 1969. Effect of plant age and nitrogen fertilization on chemical composition and in vitro cellulose digestibility of tropical grasses. Agron. J. 61, 116.

Hatfield, R.D., Jung, H.J., Ralph, J., Buxton, D.R. \& Weimer, P.J., 1994. A comparison of the insoluble residues produced by the klason lignin and acid detergent lignin procedures. J. Sci. Food Agric. 65, 51.

Hogan, J.P., Weston, R.H. \& Lindsay, J.R., 1969. The digestion of pasture plants by sheep. IV. The digestion of Phalaris tuberosa at different stages of maturity. Aust. J. Agric. Res . 20, 925.

Jung, H.J. \& Vogel, K.P., 1992. Lignification of Switchgrass and Big Bluestem plant parts during maturation and its effect on fibre degradability. J. Sci. Food Agric. 59, 169.

Kabunga, J.D. \& Darko, C.A., 1993. In sacco degradation of dry matter and nitrogen in oven dried and fresh tropical grasses and some relationships to in vitro dry matter digestibility. Anim. Feed Sci. Tech . 40, 191.

Kephart, K.D. \& Buxton, D.R., 1993. Forage quality responses of C3 and C4 perennial grasses to shade. Crop Sci. $33,831$.

Langlands, J.P., 1975. Techniques for estimating nutrient intake and its utilisation by the grazing ruminant. In: Digestion and metabolism in the ruminant. Eds. McDonald, I.W. \& Warner, A.C.I. University of New England Publishing Unit, Armidale.

Laredo, M.A. \& Minson, D.J., 1973. The voluntary intake, digestibility, and retention time of the leaf and stem fractions of five grasses. Aust. J. Agric. Res. 24, 875.

MacRae, J.C. \& Lobley, G.E., 1982. Some factors which influence thermal energy losses during the metabolism of ruminants. Livest. Prod. Sci. 9, 447.

MacRae, J.C., Smith, J.S., Dewey, P.J.S., Brewer, A.C., Brown, D.S. \& Walker, A., 1985. The efficiency of utilization of metabolizable energy and apparent absorption of amino acids in sheep given spring- and autumn-harvested dried grass. Br. J. Nutr. 54, 197.

Meissner, H.H., Smuts, M., Van Niekerk, W.A. \& Acheampong-Boateng, O., 1993. Rumen ammonia concentrations, and non-ammonia nitrogen passage to and apparent absorption from the small intestine of sheep ingesting subtropical, temperate and tannin containing forages. S. Afr. J. Anim. Sci . 23, 92.

Minson, D.J., 1971. The digestibility and voluntary intake of six varieties of Panicum. Aust. J. Exp. Agric. Anim. Husb. 11, 18.

Minson, D.J., 1972. The digestibility and voluntary intake by sheep of six tropical grasses. Aust. J. Exp. Agric. Anim. Husb. 12, 21.

Minson, D.J., 1982. Effects of chemical and physical composition of herbage eaten upon intake. In: nutritional limits to animal production from pastures. Ed. J.B. Hacker, C.A.B. Farnham Royal.

O'Reagain, P.J. \& Owen-Smith, R.N., 1996. Effect of species composition and sward structure on dietary quality in cattle and sheep grazing South African Sourveld. J. Agric. Sci., Camb. 127, 261.

O’Reagain, P.J., Goetsch, B.C. \& Owen-Smith, R.N., 1996. Effect of species composition and sward structure on the ingestive behaviour of cattle and sheep grazing South African Sourveld. J. Agric. Sci., Camb. 125, 127. 
Orskov, E.R., Grubb, J.A., Smith, J.S., Webster, A.J.F. \& Corrigall, W., 1979. Efficiency of utilization of volatile fatty acids for maintenance and energy retention by sheep. Br. J. Nutr. 41, 541.

Orskov, E.R., 1982. Protein nutrition in ruminants. Academic Press, Londen.

Playne, M.J. \& Kennedy, P.M., 1976. Ruminal volatile fatty acids and ammonia in cattle grazing dry tropical pastures. J. Agric. Sci., Camb. 86, 367.

Robertson, J.B. \& Van Soest, P.J., 1981. The detergent system of analysis and its application to human foods. In: The analysis of dietary fibre in food. Eds. W.P.T. James \& O. Theander. Marcel Dekker, New York. pp. 123.

Samuels, M.L., 1989. Statistics for the life sciences. Collier MacMillan Publishers, Londen.

Statistical analysis systems, 1994. SAS User's Guide: Statistics Version 6. SAS Institute. Inc. Cary, NC., USA..

Satter, L.D. \& Slyter, L.L., 1974. Effect of ammonia concentration on rumen microbial protein production in vitro. Br. J. Nutr. 32, 199.

Singh, D.K., Singh, V. \& Sale, P.W.G., 1995. Effect of cutting management on yield and quality of different sections of Guinea grass (Panicum maximum [Jacq.]L.) in a humid sub-tropical environment. Trop. Agric. $72,181$.

Van Soest, P.J., 1965. Symposium on factors influencing the voluntary intake of herbage by ruminants. Voluntary intake in relation to chemical composition and digestibility. J. Anim. Sci. 24, 834.

Van Soest, P.J., 1982. Nutritional ecology of the ruminant. O \& B Books, Corvallis, Oregon.

Walker, D.J., Egan, A.R., Nader, C.J., Ulyatt, M.J. \& Storer, G.B., 1975. Rumen microbial protein synthesis and proportions of microbial and non-microbial nitrogen flowing to the intestines of sheep. Aust. J. Agric. Res. 26, 699.

Wan Hassan, W.E., Phipps, R.H. \& Owen, E., 1990. Dry matter yield and nutritive value of improved pasture species in Malaysia. Trop. Agric. 67, 303. 